\title{
Plant Diversity in an Intensively Cultivated Vineyard Agro- ecosystem (Langhe, North-West Italy)
}

\author{
E. Mania ${ }^{1}$, D. Isocrono ${ }^{1}$, M.L. Pedullà ${ }^{2}$, S. Guidoni ${ }^{*}$ \\ (1) Department of Agricultural, Forest and Food Sciences, University of Turin, Largo Braccini, 2 - 10095 Grugliasco, Italy \\ (2) Coop. Clorofilla, Giardino Botanico di Oropa, Loc. Oropa - 13900 Biella, Italy
}

Submitted for publication: April 2015

Accepted for publication: October 2015

Key words: Biodiversity, cover crop, field margin, flora, species richness

\begin{abstract}
In areas of intensive agriculture, wild plant species are confined to field margins, thus they play a role in protecting biodiversity. The aim of the present study was to assess plant diversity in an area of intensive viticulture and to evaluate, for the first time, the impact of field margins on vineyard flora biodiversity. The study was conducted in North-West Italy, were five categories of floristic lists in vineyard-margin pairs were sampled and compared. Five margins were identified: grass-covered (A) and bare (B) headlands, small (C) and wide (D) woodlands, and shrub and herbaceous (E) areas. Two hundred and fifty-two taxa were found, although only 19 were widespread. Differences among categories emerged, highlighting the high floristic complexity of the sites surrounded by wide wooded areas (D). The findings suggest an influence of margin size, in addition to margin type, on the floristic richness of the vineyard. Moreover, an inverse relationship between species richness and both the presence of Poaceae and the degree of soil grass coverage emerged. Enhancing biodiversity, at landscape and field level, by the appropriate management of cover crops and ecological infrastructures, within and around vineyards, could be a strategy in sustainable viticulture. The increase in plant species richness is not an end in itself, but it might help to promote biodiversity at different trophic levels.
\end{abstract}

\section{INTRODUCTION}

Areas dominated by intensive agriculture have shown, in the last decades, a simplification of the agro-ecosystem (Benton et al., 2003) and a consequent decrease in biodiversity (Tscharntke et al., 2005; 2012; Krauss et al., 2010; Flohre et al., 2011; Winqvist et al., 2011; Postma-Blaauw et al., 2012) associated with agricultural management (Kleijn \& Snoeijing, 1997; Longley et al., 1997; Benton et al., 2002; Schmitz et al., 2014a). Many of these areas are characterised by strong crop specialisation (monoculture) and by a decrease in semi-natural habitats; in these circumstances, field margins are the only habitat in which it is possible to find various wild plant species. They could play a key role in protecting and enhancing the biodiversity of the agrosystem (Marshall \& Moonen, 2002) that, in turn, provides several ecosystem services that contribute to pollination, natural pest control and soil fertility (Zhang et al., 2007).

The abundance, richness and diversity of biotic populations (e.g. beneficial arthropods) within an agrosystem are, however, highly dependent on the area's plant community richness (Altieri, 1999), even if they may vary within the cultivated field, also because plant species richness decreases from the edge to the centre of the field
(Debras et al., 2008; Thomson \& Hoffmann, 2009; Poggio et al., 2013; Molina et al., 2014). The species richness (plants and arthropods) and abundance that normally are observed in the edges occur mainly in more stable conditions with richer resources within semi-natural habitats, rather than in productive fields (Marshall \& Moonen, 2002). In an anthropic area, field margins may correspond to a wide range of natural or anthropogenic structures (Greaves \& Marshall, 1987; Burel, 1996; Marshall \& Moonen, 1998; Schmitz et al., 2013). The capacity of field margins to contribute to ecosystem biodiversity conservation depends on the complexity of the agro-ecosystem, the margin size and the agricultural management strategy adopted in the adjoining fields (Bäckman \& Tiainen, 2002; Socher et al., 2013; Schmitz et al., 2014b). Large field margins have a wider species richness and density than narrow margins, but unfortunately, in intensely cultivated areas, narrow field margins predominate, and margins narrower than three metres are thought to be unable to protect wild communities (Hahn et al., 2014).

Over time, the impact of agricultural management leads to a change in the composition of the plant community, even in the field margins, and also causing a loss of biodiversity

*Corresponding author: E-mail address: silvia.guidoni@unito.it

Acknowledgements: The research was carried out with financial support from the University of Turin (ex 60\%) 
(Schmitz et al., 2014a). However practices more respectful of biocenosis, such as those employed in organic farming, seem to ensure a greater plant species richness in cultivated and surrounding areas (Aude et al., 2003; Hole et al., 2005; Damgaard et al., 2014). This increase in biodiversity promotes, in turn, more effective biological control in heterogeneous landscapes (Bengtsson et al., 2005; Winqvist et al., 2011).

Among crops, vineyards may play an important role in preserving agro-ecosystem biodiversity, as they are permanent and heterogeneous systems with a multi-strata design (Simon et al., 2010), where vine rows alternate with potentially undisturbed strips, or at least less disturbed when compared with annual crops or orchards (Bruggisser et al., 2010). The potential contribution of vineyards to increasing agrosystem biodiversity, and plant diversity in particular, however, depends on the landscape characteristics, the adopted agriculture strategy (i.e. conventional, integrated, organic) (Nascimbene et al., 2012) and the management and characteristics of neighbouring areas (Thomson \& Hoffmann, 2009; Simon et al., 2010). These are some of the reasons why conflicting results emerged from the few studies on plant diversity in vineyards (Gago et al., 2007; Bruggisser et al., 2010; Nascimbene et al., 2012; 2013).

The role of field margins in vineyards has been investigated even less (Thomson \& Hoffmann, 2009). In areas characterised by intensive agriculture, organic farming promoted plant species richness within the vineyard and in the adjacent grass strips, while no effects were observed on the surrounding margins (Nascimbene et al., 2012).

Other studies (e.g. Bruggisser et al., 2010) state that no differences exist between organic and conventional vineyards regarding plant species diversity and abundance in the grass strips. However, there is evidence that cover crop management (i.e. mowing vs. mulching, mowing frequency, fertilisation, tillage, chemical weeding, sowing) has a strong impact on natural plant coverage (Gay et al., 1998; Gago et al., 2007; Nascimbene et al., 2013; Trivellone et al., 2014).

The impact of margins on vineyard biodiversity may be different according to the margins' physionomy: the wooded ones have been found to play a positive role in promoting the presence of beneficial arthropods and in encouraging both parasitism and predation phenomena, whereas the herbaceous ones were found to have no effect on arthropod communities (Thomson \& Hoffmann, 2009).

Piedmont (North-West Italy) is one of the most important Italian regions for wine production: 2.86 million hl of wine and 50737 ha of vineyards (Regione Piemonte, 2009). The Langhe is an intensively cultivated hilly district of this region where Barolo, one of the most prestigious and lucrative Italian wines, is produced. According to the technical production policy, this wine may be produced in only eleven municipalities where viticulture represents the main crop, with precisely $83 \%$ (1 046 ha) of the utilised agricultural area (UAA) in three municipalities and $42 \%$ (2 983 ha) of the UAA in the other eight (Sistema Piemonte, 2014).

Due to the high economic value of production, and against the trend in neighbouring viticultural areas, the vineyard surface in the area of Barolo production has increased by about $6 \%$ in the last six years. In this framework, the natural or semi-natural vegetation is restricted to small, scattered forest patches or uncultivated areas, and biodiversity loss is more and more likely. Some growers are starting to create some sort of ecological corridors close to the vineyards to stimulate entomofauna propagation. However, even the maintenance of grassy areas within the vineyard (typically the inter-row spaces) may be useful to preserve or increase agro-ecosystem biodiversity, in addition to ensuring countless other agronomic and ecological services.

But what are the variables that can help achieve this goal? It has been highlighted that field management techniques and geographic features may influence vineyard plant species richness (Passarelli \& Pirola, 1990; Dujmović Purgar \& Hulina, 2004; Monteiro \& Moreira, 2004; Gago et al., 2007; Bruggisser et al., 2010; Nascimbene et al., 2013; Trivellone et al., 2014). Only a couple of studies have considered the impact of margin type on arthropod communities (Debras et al., 2008; Thomson \& Hoffmann, 2009) but, to our knowledge, no study has considered the possible margin effect on the diversity of vineyard flora.

In analogy with some observations made on arthropods, our hypothesis was that the surrounding environment may influence the diversity of flora within vineyards. Therefore, if the management of the field margins is addressed specifically it could be useful for conserving and/or improving biodiversity (vegetal and animal), even in very specialised agrosystems. Considering the importance of biodiversity from an ecological, agronomic and economic point of view, and also its vulnerability, especially in intensively cultivated areas, the study was carried out with a dual objective. The first was to provide information about the richness and composition of the flora in the poorly-explored Langhe viticultural ecosystems (vineyards and their adjoining margins), also in comparison with other wine-growing areas. The second was to discover the influence the type and size of margins have on the diversity of vineyard flora to support the importance of creating and maintaining infrastructure around vineyards that are able to promote agrosystem biodiversity.

\section{MATERIALS AND METHODS}

The study was carried out on a surface of $80 \mathrm{~km}^{2}$ in the Langhe wine-growing area (Piedmont, North-West Italy) and precisely in the Barolo production zone (administrative epicentre 4436’31.99’ N, 756’24.79’'E, 326 m above sea level); this is a temperate area where the main annual meteorological values for the period 1996 to 2014 were, on average: annual rainfall $833 \mathrm{~mm}$, maximum temperature $17.9^{\circ} \mathrm{C}$, minimum temperature $8.1^{\circ} \mathrm{C}$. Nebbiolo mainly is cultivated in this area; vines are vertically shoot trained; the canopy height is around $180 \mathrm{~cm}$; and vineyard density is on average 4000 plants/ha. Vineyard surface ranges from 0.3 to 2 ha according to the great extent of dividing up property that is typical of the study area. Vineyard soil is usually tilled in alternate rows and alternate years during the autumn-winter season; in the growing season the natural grass is allowed to grow spontaneously in the inter-rows and mowed regularly, whereas under the vines the soil is bare or irregularly covered by grass according to the soil management technique, tillage or chemical weeding (fall-spring glyphosate). 
The study was carried out on 33 sites; in each site we considered both commercial vineyards (V) and their adjoining margins (M). Vineyards were selected according to the type of surrounding margin (see below). Grass sowing was not used in any of these vineyards.

Since the vineyards presented homogeneous spontaneous vegetation, three to five plots, with a total surface of 200 $\mathrm{m}^{2}$, were randomly distributed depending on the surface occupied by the margins and vineyard in each site. In each plot, all vascular plants were sampled; the plant coverage (i.e. the percentage of soil covered by grass estimated as the portion of soil occupied by the perpendicular projection of the aerial part of the plants) was also estimated in the vineyards. Samplings were conducted once between the vine phenological stages of flowering and véraison in 2014. Plant species were identified according to Pignatti (1982). Nomenclature followed Conti et al. (2005).

To achieve the first objective of the study, data were analysed to highlight the most frequent species occurring in the Langhe winegrowing sites, i.e. those found in at least $50 \%$ of the surveyed area (vineyards or margins). We also present the species shared between our list and the few available lists drawn up in other winegrowing areas. The available studies deal with Valtellina, North-West Italy (Passarelli \& Pirola, 1990), the Jastrebarsko area in North-West Croatia (Dujmović Purgar \& Hulina, 2004), West-Central Portugal (Monteiro \& Moreira, 2004), North-Western Spain (Gago et al., 2007), Northern Switzerland (Bruggisser et al., 2010), North-Eastern Italy (Nascimbene et al., 2013) and Southern Switzerland (Trivellone et al., 2014).

In order to estimate the impact of the margin type and size on vineyards biodiversity (second objective), five categories of vineyard-margin pairs (named "category" in the text) were identified a priori, taking into account the specificity of the area: A) vineyards interspersed with headlands transited by tractors and coupled equipment along the contour lines and usually grass covered $(\mathrm{n}=10) ; \mathbf{B})$ vineyards interspersed with headlands transited along the maximum hill slope gradient, highly disturbed and almost devoid of vegetation $(\mathrm{n}=14) ; \mathbf{C})$ vineyards flanked by small (average surface 0.6 ha) portions of wooded unmanaged areas that are quite far from being natural $(n=6)$; D) vineyards bordered by large (average surface $1.3 \mathrm{ha}$ ) unmanaged woods close to natural environmental conditions $(\mathrm{n}=6)$; and $\mathbf{E})$ vineyards flanked by small (average surface $0.06 \mathrm{ha}$ ) shrub and herbaceous areas $(n=4)$.

Both the floristic profile and the total number of species found in each vineyard-margin category $(\mathrm{A}, \mathrm{B}, \mathrm{C}, \mathrm{D}, \mathrm{E})$ and within vineyards or within margins were recorded, regardless of whether they were shared between the vineyard and the margin or not.

In order to explore potential differences between categories related to the floral composition of the vineyards and margins, analysis of variance (ANOVA) was carried out on the variables identified to characterise the sites. These were: the species number in the vineyard and in the margin, the number of shared species, the percentage of exclusive species (to the vineyard or to the margin), and the percentage of vineyard soil covered by grass. To assess the significance of differences, the Duncan test was used. Multivariate principal component analysis (PCA) was afterwards performed on the same dataset. Both statistical analyses were performed by means of SAS Software (SAS Institute Inc., Cary, NC, USA).

Finally, the vineyards and margins of each category were characterised according to other variables, such as the percentage of tree species, Poaceae, and typical species (i.e. species frequent in and exclusive to the considered category), calculated on the basis of the total number of species. The percentages of Poaceae and tree species were calculated as an indication of the degree of soil coverage and the structure of the plant communities respectively. The number of typical species was calculated as an indication of the degree of diversity and peculiarity of the plant community surveyed in each category - the higher the value, the more typical the plant assemblage. The frequent species value indicated the level of homogeneity of flora within the category - the higher the value, the more homogeneous the vineyards or margins within the same category.

\section{RESULTS}

A total of 252 plant species were found in the investigated area: 177 (belonging to 42 families) in the vineyards and 195 (belonging to 54 families) in the margins. These species were differently distributed among the sites. Despite the high number of recorded species, only 19 species occurred frequently in the vineyards. Seven of these also were frequent in the margins (Table 1). Fifty species, 12 of which were frequent in the vineyards in Langhe, had also been sampled in other winegrowing districts of different geographic areas (Northern Italy, North-Western Croatia, West-Central Portugal, North-Western Spain, Switzerland) (Table 2).

For each category, the species occurring both in the vineyards and in the margins were identified (Table 3); the shared species varied to a great extent, depending on the category, from 2 in B to 19 in E.

The total number of species sampled in all vineyardmargin pairs was calculated, separating the vineyard richness from that of the margins (Table 4). The species richness in the A, B and D vineyards (V) was around 120 species, whereas in $\mathrm{C}$ and $\mathrm{E}$ the value was less than half that. Considering the margins (M), the richest were $\mathrm{C}$ and $\mathrm{D}$, with 121 and 125 species respectively, whereas the value decreased dramatically in B (28 species). The total species richness of the categories was very variable, particularly considering the richest category (D, with 175 species) and the poorest one (E with 96 species). Since the shared species were counted only once, the higher their number, the greater the difference between the arithmetic sum ' $\mathrm{V}+\mathrm{M}$ ' and ' $\mathrm{T}$ '.

Looking at the results more deeply, some differences emerged among categories when average values were considered (Table 5). Concerning vineyards, a significantly higher species richness was recorded in D (46 species) with respect to $\mathrm{B}, \mathrm{C}$ and $\mathrm{E}$ ( 27 species) where the lowest values were observed; an intermediate amount was found in A (33 species). In the margins, the greatest species richness was observed in C, D and E (42 species on average); A and B showed significantly lower values (20 and 5 species respectively). These two values were the lowest even when compared to the other margins or to their own adjoining 
TABLE 1

Frequency of species in Langhe area. Only data over 50\% are reported for vineyards and margins.

\begin{tabular}{|c|c|c|c|}
\hline Plant species & Family & $\begin{array}{c}\% \text { of } \\
\text { vineyards }\end{array}$ & $\%$ of margins \\
\hline Convolvolus arvensis L. & Convolvulaceae & 97 & 94 \\
\hline Taraxacum officinale Weber s.l. & Asteraceae & 91 & 79 \\
\hline Verbena officinalis L. & Verbenaceae & 88 & - \\
\hline Trifolium repens L. & Fabaceae & 82 & - \\
\hline Medicago lupulina $\mathrm{L}$. & Fabaceae & 79 & 52 \\
\hline Trifolium pratense L. & Fabaceae & 79 & - \\
\hline Veronica persica Poiret & Scrofularieceae & 79 & - \\
\hline Erigeron annuus (L.) Pers. & Asteraceae & 76 & 61 \\
\hline Lolium perenne L. & Poaceae & 76 & 58 \\
\hline Cirsium arvense (L.) Scop. & Asteraceae & 73 & 55 \\
\hline Picris echioides L. & Asteraceae & 73 & - \\
\hline Lysimachia arvensis (L.) U. Manns \& Anderb. subsp. arvensis & Primulaceae & 70 & 64 \\
\hline Plantago lanceolata L. & Plantaginaceae & 70 & - \\
\hline Rumex crispus L. & Polygonaceae & 67 & - \\
\hline Sonchus asper (L.) Hill & Asteraceae & 64 & - \\
\hline Hordeum leporinum Link & Poaceae & 58 & - \\
\hline Bromus hordaceus L. & Poaceae & 55 & - \\
\hline Conyza sp. & Asteraceae & 52 & - \\
\hline Plantago major L. & Plantaginaceae & 52 & - \\
\hline
\end{tabular}

vineyards. A significantly lower number of shared species was recorded in B (4 species) when compared with A, D and $\mathrm{E}$ (16 species on average). In $\mathrm{C}$, an intermediate situation was observed (10 species). As far as exclusive species are concerned, the E vineyards showed a significantly lower percentage $(31 \%$, on average), while the $\mathrm{B}$ vineyards showed a significantly higher percentage ( $86 \%$, on average), consistently with the few species sampled within the margin and the poor grass coverage of the margin itself.

On the basis of these variables, the principal component analysis (PCA) distributed the 33 sites on the plane defined by the two first principal components (Prin 1 and Prin 2), which together explained $76 \%$ of the total variance (Table 6); the identifiable groups were quite similar to the preset ones (Fig. 1). PCA well separated the B category from the others and, in particular, from $\mathrm{D}$ and $\mathrm{E}$, which had richer margins and a greater number of shared species (Table 5). The sites in the $\mathrm{A}$ and $\mathrm{B}$ categories, which were more dispersed on the plane, especially along Prin2, were less homogeneous than the other three, especially regarding vineyards species richness and grass coverage of the soil (variables associated with Prin 2) (Table 6). Conversely, the limited dispersion of the $C$ and D sites along Prin2 highlighted their great homogeneity in relation to the $\mathrm{V}$ species' richness and degree of coverage; the latter variable achieved the maximum value in the $\mathrm{C}$ vineyards (Table 5), despite their limited species richness. The E sites, on the other hand, were the most homogeneous regarding the margin species richness. As emerged from the PCA, the V species richness and the degree of grass coverage were inversely proportional with each other.

The extraction of variables from the complete floristic list of each category revealed other differences (Table 7). In A, D and E, a similar percentage of shared species (42\%) was observed, but, in the $\mathrm{D}$ and $\mathrm{E}$ margins, the percentage of exclusive species was higher (31 and $47 \%$ respectively), even though their species richness was very different (125 vs 86, Table 4). In the A and B margins, which were limited to the headlands, the percentage of exclusive species was very low; in the first case, many species were in common with the vineyard, and in the second the margins were very poor. According to the percentage of frequent species in the $\mathrm{A}$ and $\mathrm{B}$ categories, both margins and vineyards were very heterogeneous; in contrast, the E category was the most homogeneous. The composition of flora in both the A and $\mathrm{B}$ margins and vineyards was not particularly typical; in contrast, those of the E margin and D vineyards were the most distinct.

The $\mathrm{C}$ and $\mathrm{D}$ margins showed the highest percentage of tree species and the lowest of Poaceae, which, in turn, were more diffused in the A, B and E margins and vineyards. Some tree species were also recorded in the A and E margins, but none in the $\mathrm{B}$ margins. The $\mathrm{D}$ vineyard hosted very few Poaceae, while the number recorded in the $\mathrm{C}$ vineyard was similar to that found in the A and $\mathrm{E}$ vineyards (Table 7).

\section{DISCUSSION}

A total of 252 infrageneric taxa were identified in the Langhe vineyards and their adjoining margins. This is quite similar to the data reported in studies analysing the vineyard habitats as a whole in Switzerland (259 vs 252) and in Eastern Italy (211 vs 252). The plant richness recorded only in the vineyards (177 species, 33 sites) was comparable with that 
TABLE 2

Plant species shared between Langhe and other winegrowing European areas: a) North-Western Italy (Passarelli \& Pirola, 1990), b) North-Western Croatia (Dujmović Purgar \& Hulina, 2004), c) West-Central Portugal (Monteiro \& Moreira, 2004), d) North-Western Spain (Gago et al., 2007), e) Northern Switzerland (Bruggisser et al., 2010), f) North-Eastern Italy (Nascimbene et al., 2013), g) Southern Switzerland (Trivellone et al., 2014).

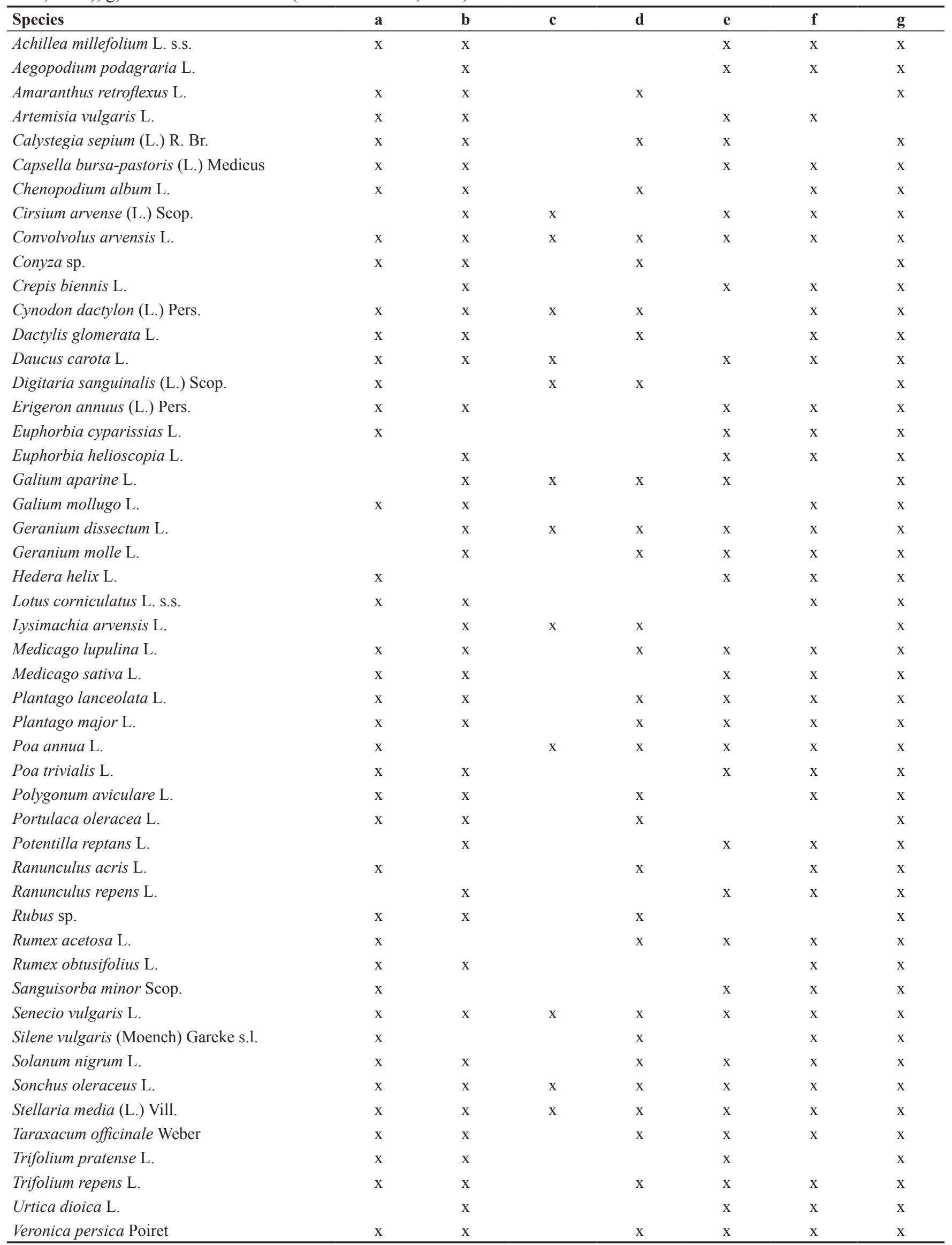




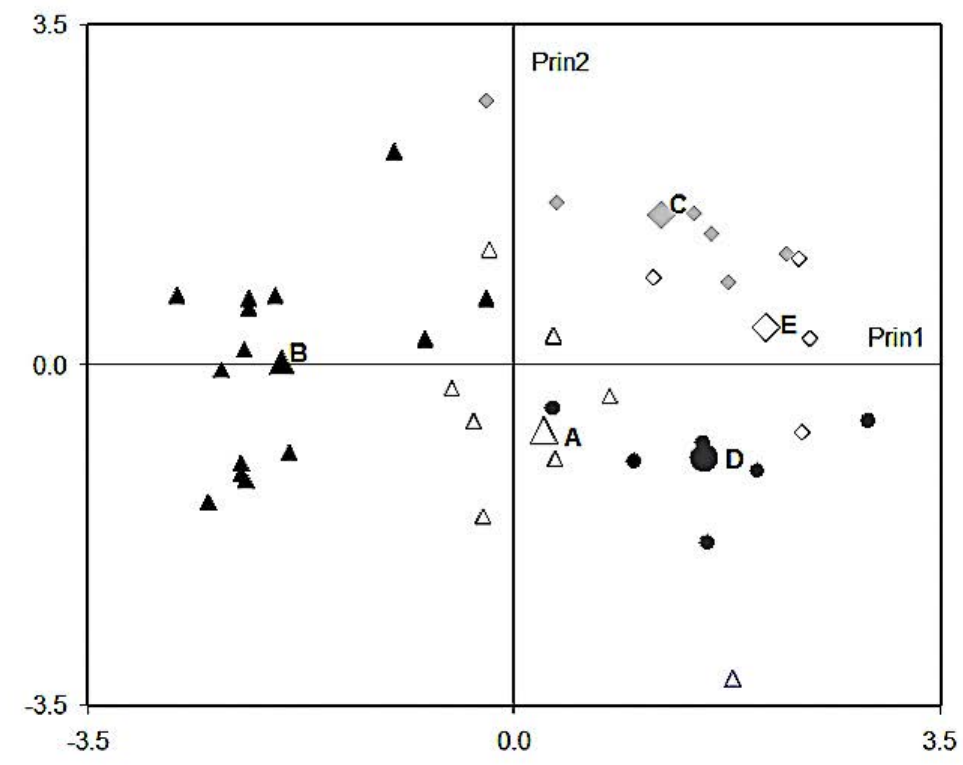

FIGURE 1

Distribution of the sites in the Cartesian coordinate system included in the first two principal components (Prin 1 vs Prin 2) obtained from a model with six variables (see also Table 6).

$\Delta=\mathrm{A} ; \boldsymbol{\Delta}=\mathrm{B}, \diamond=\mathrm{C} ; \bullet=\mathrm{D} ; \diamond=\mathrm{E}$ (the centroid of each group is identified by the largest symbol).

reported in other studies carried out in Italy (Nascimbene et al., 2013: 141 species, 25 vineyards). The plant richness seems lower than that recorded in Switzerland (Bellosi et al., 2013: 441; Trivellone et al., 2014: 259 in 48 sites), but these studies adopted a slightly different methodology and the studied vineyards were terraced, and this human-shaped infrastructure may have contributed to the conservation of a greater number of species.

As far as vineyard flora are concerned, a certain similarity, probably due to climatic affinities, was found between the Langhe area and some sites in the Alps and PreAlps: 96 of the found taxa (equal to $38 \%$ of our flora list) are in common with Valtellina (North-West Italy) (Passarelli \& Pirola, 1990), and 103 (equal to $40 \%$ of our list) with Southern Switzerland (Trivellone et al., 2014).

In the Langhe area, Asteraceae (16\%) and Poaceae $(12 \%)$ were the most predominant families (Table 1), as also reported in other areas (Bellosi et al., 2013; Dujtmović Purgar \& Hulina, 2004). Convolvulus arvensis and Taraxacum officinale were the most frequent species, both in the vineyards and in the margins. Veronica persica, Trifolium repens and Trifolium pratense were sampled in around $80 \%$ of the vineyards, but not in the margins: these are species often recorded in vineyards, irrespective of the soil management techniques used (mowing, contact herbicides, systemic herbicides) (Dujmović Purgar \& Hulina, 2004; Gago et al., 2007). Some alien species are present in the checklist for the Langhe area, among them Conyza spp., sampled in over 52\% of the vineyards, and the most frequent in the area.

Eighteen of the 19 most widespread species (Table 1) were also present in the list of species shared between vineyards and their margins (Table 3). D and E were found to share the highest number of species; among them several were typical of these types of margins. For example, Rubus spp., Hedera helix and Hypercum perforatum, present only in the D sites, are typical of woodland habitats, and others, such as Cynodon dactylon, Setaria ambigua and Bromus hordeaceus, present in high percentages only in the E sites, are typical of agro- or natural prairies. These observations may indicate an important role of structured margins in increasing plant species richness in the vineyard and ensuring more stable ecological conditions. Only seven species occurred in all types of margins (Table 1), showing that the margin flora are far more heterogeneous than the vineyard ones. This is what makes these flora interesting to identify, also in view of evaluating their possible contribution not only to the biodiversity of the entire agrosystem, but also to that of vineyards.

In the $\mathrm{A}, \mathrm{B}$ and $\mathrm{D}$ vineyards, a similar total number of species was counted (Table 4), but the average number was definitely higher in D (Table 5); the margins of the same categories showed greater heterogeneity, both as total (Table 4) or average (Table 5) number of species, indicating a prominent role in promoting biodiversity. The A and $\mathrm{B}$ margins were both constituted by headlands: the A margins were generally grass covered, whereas the B margins were almost completely bare because of more disturbance by the manoeuvring of crawler tractors, which typically are used in slope vineyards. The most stressful situation, which emerged in B, promotes soil erosion and discourages the establishment and development of plant species. The grass coverage of the A margins, however, was not sufficient to allow a floristic richness, even comparable to the one found in D (76 vs 125 species). As was to be expected, the B margins were absolutely the poorest (28 species). In the D category, the abundance of species (175), together 
with the total and average values of the margins (125 and 43 respectively) and vineyards (120 and 46 respectively) (Tables 4 and 5), revealed a high floristic complexity of sites surrounded by wide wooded areas. The percentage $(26 \%)$ of frequent species (detected in at least $50 \%$ of the situations), and the percentage of species typical of these margins (25\%) (Table 7), also revealed their heterogeneity and the complexity of this environmental context.

TABLE 3

Species shared between vineyards and margins in each category and percentage of sampling frequency. Only data over $50 \%$ are reported.

\begin{tabular}{|c|c|c|c|c|c|}
\hline Plant species & $\mathbf{A} \dagger$ & B & $\mathbf{C}$ & $\mathbf{D}$ & $\mathbf{E}$ \\
\hline & & & $\%$ & & \\
\hline Bromus hordeaceus L. & & & & & 100 \\
\hline Cirsium arvense (L.) Scop. & 50 & & & 100 & 100 \\
\hline Convolvolus arvensis $\mathrm{L}$. & 100 & 79 & 67 & 83 & 75 \\
\hline Conyza sp. & & & & 83 & \\
\hline Crepis vesicaria L. subsp. taraxacifolia (Thuill.) Thell. & & & & 83 & \\
\hline Cynodon dactylon (L.) Pers. & & & & & 75 \\
\hline Erigeron annuus (L.) Pers. & 50 & & 83 & 67 & 75 \\
\hline Hedera helix $\mathrm{L}$. & & & & 67 & \\
\hline Hordeum leporinum Link & & & & & 75 \\
\hline Hypericum perforatum $\mathrm{L}$. & & & & 67 & \\
\hline Lolium perenne $\mathrm{L}$. & 70 & & 50 & & 75 \\
\hline Lysimachia arvensis (L.) U. Manns \& Anderb. subsp. arvensis & 80 & & 67 & 50 & 75 \\
\hline Medicago lupulina $\mathrm{L}$. & 60 & & & 50 & 75 \\
\hline Mentha sp. & & & & & 75 \\
\hline Oxalis fontana Bunge & & & & & 75 \\
\hline Picris echioides $\mathrm{L}$. & & & & 50 & 75 \\
\hline Plantago lanceolata $\mathrm{L}$. & 50 & & & & \\
\hline Rubus sp. & & & & 50 & \\
\hline Rumex crispus L. & & & 50 & & 50 \\
\hline Setaria ambigua Guss. & & & & & 50 \\
\hline Setaria viridis (L.) Beauv. & & & & 50 & \\
\hline Sinapis arvensis L. var. arvensis & & & 50 & & \\
\hline Sonchus asper (L.) Hill & & & 50 & & 50 \\
\hline Taraxacum officinale Weber & 70 & 64 & 67 & 50 & 50 \\
\hline Trifolium pratense $\mathrm{L}$. & 50 & & 50 & & \\
\hline Trifolium repens $\mathrm{L}$. & & & & & 50 \\
\hline Verbena officinalis L. & & & 50 & 50 & 50 \\
\hline Veronica persica Poiret & 70 & & & & 50 \\
\hline
\end{tabular}

$\dagger$ A) vineyards interspersed with headlands, transited by tractors and coupled equipment along the contour lines, and usually grass covered, B) vineyards interspersed with headlands transited along the maximum hill slope gradient, highly disturbed and almost devoid of vegetation, C) vineyards flanked by small portions of wooded unmanaged areas, D) vineyards bordered by unmanaged woods, E) vineyards flanked by small shrub and herbaceous areas.

TABLE 4

Total number of species recorded for each category $(\mathrm{T})$ and plant species richness within vineyards (V) or within margins (M), regardless of whether they were shared.

\begin{tabular}{lcccc}
\hline Category $\dagger$ & Number of sites & V & M & T \\
\hline A & 10 & 123 & 76 & 138 \\
B & 14 & 121 & 28 & 122 \\
C & 6 & 60 & 121 & 143 \\
D & 6 & 120 & 125 & 175 \\
E & 4 & 51 & 86 & 96 \\
\hline
\end{tabular}

$\dagger$ A) vineyards interspersed with headlands, transited by tractors and coupled equipment along the contour lines, and usually grass covered, B) vineyards interspersed with headlands transited along the maximum hill slope gradient, highly disturbed and almost devoid of vegetation, C) vineyards flanked by small portions of wooded unmanaged areas that were quite far from being natural, D) vineyards bordered by unmanaged woods close to natural environmental conditions, E) vineyards flanked by small shrub and herbaceous areas. 
When the total plant richness of C and D (both examined in six sites), as well as vineyard richness (143 vs 175 and 60 vs 120 respectively, Table 4) were considered, large differences between categories emerged (Fig. 1), whereas a similar number of species was detected in the margins when the average value (42, Table 5) or the total species number (123, Table 4 and Fig. 1) was taken into account. Conversely, the number of species exclusive to the margins was higher in $\mathrm{C}$ (Table 5) (76\% of total species) than in $\mathrm{D}$
$(60 \%)$. The D margins showed a high number of species shared with their adjacent vineyards (Table 5). These, in turn, had a greater species richness when compared not only with the $\mathrm{C}$ vineyards, but also with all the others (Table 5). Since the $\mathrm{C}$ and $\mathrm{D}$ margins differed in the size of the wooded area, but not in the percentage of trees (19\% of total species sampled) or Poaceae species (13\% of the total) (Table 7$)$, the differences observed between them suggested a possible influence of the margin size, in addition to the margin type,

TABLE 5

Average plant species richness in each site category. Site category, plant species richness in the vineyard and in the margin, number of shared species between vineyards and their adjoining margin, percentage of exclusive species to the vineyards (V) or to the margin $(\mathrm{M})$, percentage of vineyard soil covered by grass.

\begin{tabular}{lllllll}
\hline Category $\dagger$ & $\begin{array}{l}\text { Vspecies } \\
\text { richness (n.) }\end{array}$ & $\begin{array}{l}\text { M species } \\
\text { richness (n.) }\end{array}$ & $\begin{array}{l}\text { Shared species } \\
(\mathbf{n} .)\end{array}$ & $\begin{array}{l}\text { V exclusive } \\
\text { species (\%) }\end{array}$ & $\begin{array}{l}\text { M exclusive } \\
\text { species (\%) }\end{array}$ & $\begin{array}{l}\text { V grass } \\
\text { coverage (\%) }\end{array}$ \\
\hline $\mathbf{A}$ & $32.7 \mathbf{a b t}$ & $19.6 \mathbf{b}$ & $13.4 \mathbf{a}$ & $57.2 \mathbf{b}$ & $31.7 \mathbf{b c}$ & $72.5 \mathbf{a b}$ \\
$\mathbf{B}$ & $30.5 \mathbf{b}$ & $4.6 \mathbf{c}$ & $3.9 \mathbf{b}$ & $85.7 \mathbf{a}$ & $7.8 \mathbf{c}$ & $69.6 \mathbf{a b}$ \\
$\mathbf{C}$ & $24.7 \mathbf{b}$ & $41.7 \mathbf{a}$ & $10.5 \mathbf{a b}$ & $60.3 \mathbf{b}$ & $76.3 \mathbf{a}$ & $89.2 \mathbf{a}$ \\
$\mathbf{D}$ & $46.0 \mathbf{a}$ & $43.0 \mathbf{a}$ & $17.7 \mathbf{a}$ & $60.3 \mathbf{b}$ & $59.6 \mathbf{a b}$ & $62.5 \mathbf{b}$ \\
$\mathbf{E}$ & $25.3 \mathbf{b}$ & $41.5 \mathbf{a}$ & $17.3 \mathbf{a}$ & $31.2 \mathbf{c}$ & $57.5 \mathbf{a b}$ & $71.3 \mathbf{a b}$ \\
\hline
\end{tabular}

$\dagger$ A) vineyards interspersed with headlands, transited by tractors and coupled equipment along the contour lines, and usually grass covered, B) vineyards interspersed with headlands transited along the maximum hill slope gradient, highly disturbed and almost devoid of vegetation, C) vineyards flanked by small portions of wooded unmanaged areas that were quite far from being natural, D) vineyards bordered by unmanaged woods close to natural environmental conditions, E) vineyards flanked by small shrub and herbaceous areas. $\$$ Means followed by different letters significantly differ for $\mathrm{P}<0.05$ at the Duncan test.

\section{TABLE 6}

Principal component analysis: contribution of the three principal components (Prin 1, Prin 2, Prin 3) to total variance, related eigenvalues; eigenvectors of the six variables on the first three principal components (the values of the most important variables explaining the variability along the relative principal component are shown in bold).

\begin{tabular}{llll}
\hline & Prin 1 & Prin 2 & Prin 3 \\
\hline Partial variance (\%) & 0.51 & 0.25 & 0.14 \\
Eigenvalues & 3.03 & 1.49 & 0.83 \\
Eigenvectors: & & & $\mathbf{0 . 7 2 2}$ \\
V species richness (n.) & 0.054 & $\mathbf{0 . 6 0 4}$ & 0.068 \\
M species richness (n.) & $\mathbf{0 . 5 5 1}$ & 0.063 & -0.006 \\
Shared species (n.) & $\mathbf{0 . 5 0 1}$ & -0.329 & 0.292 \\
V exclusive species (\%) & $\mathbf{- 0 . 5 1 6}$ & 0.058 & 0.117 \\
M exclusive species (\%) & 0.416 & 0.399 & 0.612 \\
V grass coverage (\%) & 0.045 & $\mathbf{0 . 5 6 0}$ & \\
\hline
\end{tabular}

TABLE 7

Variables extracted from the complete floristic list of each category: data are expressed as percentage of total number of species found in all vineyards and margins of each category (see Table 4).

\begin{tabular}{lcccccccccc}
\hline Category & Tree species & \multicolumn{2}{c}{ Poaceae } & \multicolumn{3}{c}{ Exclusive species } & Shared species & Frequent species $\dagger$ & \multicolumn{2}{c}{ Typical species $\dagger \dagger$} \\
& M & M & $\mathbf{V}$ & $\mathbf{M}$ & $\mathbf{V}$ & & $\mathbf{M}$ & $\mathbf{V}$ & $\mathbf{M}$ & $\mathbf{V}$ \\
\hline $\mathbf{A}$ & 5 & 20 & 20 & 11 & 45 & 44 & 17 & 16 & 15 & 0 \\
$\mathbf{B}$ & 0 & 29 & 17 & 1 & 77 & 22 & 7 & 19 & 0 & 4 \\
$\mathbf{C}$ & 19 & 12 & 20 & 57 & 15 & 26 & 31 & 36 & 19 & 9 \\
$\mathbf{D}$ & 18 & 13 & 13 & 31 & 29 & 40 & 26 & 33 & 25 & 35 \\
$\mathbf{E}$ & 5 & 20 & 22 & 47 & 10 & 42 & 81 & 54 & 45 & 8 \\
\hline
\end{tabular}

$\uparrow$ Species found in at least $50 \%$ of the $\mathrm{V}$ or $\mathrm{M}$ of the category; $\uparrow \uparrow$ Frequent species exclusive of the considered category. 
on the floristic richness of the vineyard. In addition to giving this ecosystem more structure, the bigger size of the margins could have had a marked influence on the microclimate of the adjacent vineyards. It is known, in fact, that the presence of a wood can induce a greater "freshness", even in the neighbouring environment, by reducing temperatures and system evapotranspiration; this cooler environment would be suitable to the development/spreading of a richer floristic community. The high percentage of species typical of the $\mathrm{D}$ vineyards (35\%) may confirm this hypothesis; in fact, it was higher than all other vineyard categories, while it was less than $10 \%$ on average (Table 7 ). Some of these species were found only in the vineyards, others also in the margins; among the latter, some were more frequent in the margins (Hedera helix, Hypericum perforatum, Rubus sp.), some in the vineyards (Blackstonia perfoliata, Bromus sterilis, Leucanthemum vulgare and Setaria viridis), and others were found with the same frequency in both (Lactuca serriola and Quercus spp.). It can be assumed that, under these conditions, some species can easily colonise surrounding habitats (from margin towards vineyards and vice versa). We therefore can assume that the first three species mentioned above, typical of forest environments, found a favourable environment even in the vineyards, so they "migrated" from the margin towards the vineyards, and those normally present in meadows followed the opposite path.

Despite a similar species richness in the $\mathrm{C}, \mathrm{D}$ and $\mathrm{E}$ margins (Table 5), the profile of the flora varied to a great extent; in the E margins, in fact, Poaceae and tree species represented $20 \%$ and $5 \%$ of the total number of species respectively; conversely, in $\mathrm{C}$ and $\mathrm{D}$, tree species represented about $19 \%$ and Poaceae about $12 \%$. The lowest degree of coverage (62\%) and the lowest presence of Poaceae (13\%) were observed in $\mathrm{D}$ vineyards. In contrast, the $\mathrm{C}$ vineyards, despite the high coverage (89\%, Table 5 and Fig. 1), were particularly poor in species, probably due to the high presence of Poaceae (20\% of the total species, Table 7$)$. Since the Poaceae species have a high capacity for coverage, it could be assumed that, when dominant, they prevent the growth and spread of other species, thus reducing the variability of the floral composition. Nevertheless, where their diffusion is avoided, numerous other species may grow, although the degree of coverage is reduced.

The predominance of Poaceae and the minor influence of the reduced-size margin would lead to an impoverishment of vineyard biodiversity. A similar situation was observed in the E vineyards, where a high number of species shared with the margins was counted (10.5 and 17.3 for $\mathrm{C}$ and $\mathrm{E}$ respectively, Table 5), despite a limited species richness in the latter (121 and 86 for $\mathrm{C}$ and E respectively, Table 4). This shows an important equilibrium between the vineyards and margins, in addition to a high homogeneity in flora among the vineyards themselves (the frequent species were $54 \%$ in E and $36 \%$ in C) (Table 7).

Even in the herbaceous margin of E, as well as in the vineyard, a high percentage of Poaceae occurred (20 and $22 \%$ respectively), confirming the hypothesis that their abundance (Table 7) hinders the floristic diversity of the system (Table 4). According to other studies (Gago et al., 2007; Bruggisser et al., 2010; Nascimbene et al., 2012;
2013), the low number of species in vineyards may also depend on the herbaceous cover management techniques: an excessive number of cuts, or very low cutting height, impede the flowering and spreading of some species and promote or prevent the vegetative spread of others. The E category was rather poor, both in general terms and as number of species in the vineyard (Table 4); a great homogeneity among the E vineyards was observed, since more than $50 \%$ of the identified species were frequent species (Table 7).

The typical situation in the study area is represented by vineyards exclusively surrounded by headlands, such as the A and B categories. The lowest value of total species richness was found here, and this also decreased drastically in the headlands, especially in the B category (Tables 4 and 5, Fig. 1). However, the flora of these vineyards - with only $18 \%$ of frequent species - was very uneven, as also shown in the dispersion of the sites in the PCA plot (Fig. 1).

Since only non-seeded vineyards were considered, the differences within vineyards, both in composition and in species number, may depend on external influences, such as the type of vegetation surrounding the vineyard (i.e. margins) or soil and grass management, as shown in other studies (Gay et al., 1998; Gago et al., 2007; Brugisser et al., 2010; Nascimbene et al., 2012; 2013). In this area, in fact, grass may be permanently maintained or removed by autumn or spring tillage, and the intensity and number of shreddings in spring-summer can vary. Since high homogeneity was observed in some vineyard categories (D and E), despite similar grass management, it might be possible that more structured and larger margins also contribute to maintaining a certain level of homogeneity, not only between margins and vineyards, but also within the vineyards (Malcevschi et al., 1996).

\section{CONCLUSIONS}

This study has provided an in-depth description of the richness and composition of flora in the intensively cultivated agroecosystem in Italy's Langhe winegrowing area, emphasising wide similarities with other European viticultural areas. The findings confirm that plant species richness and flora composition may depend on grass coverage management, but also strongly suggest that more complex margins may improve the composition and stability of flora in the neighbouring vineyards. Apart from that, wider wooded margins, promoting fresher microclimatic conditions in the adjoining vineyards, proved to contribute more than any other margin to the preservation and enhancement of biodiversity in this agro-ecosystem.

Biodiversity needs to be protected, and possibly enriched, for its enormous ecological, agronomic and economic value. The increase in plant species richness, in fact, is not an end in itself, but might help to promote biodiversity even at different trophic levels. To enhance biodiversity and viticultural sustainability at the landscape and field level, several strategies could be applied, two of which emerged from our findings. The first concerns the application of proper cover crop management, and the second concerns the creation and maintenance of ecological infrastructure within and around vineyards, such as grass strips within vineyards (i.e. interrow spaces) and large wooded areas surrounding them. 


\section{LITERATURE CITED}

Altieri, M.A., 1999. The ecological role of biodiversity in agroecosystems. Agric. Ecosyst. Environ. 74, 19-31.

Aude, E., Tybirk, K. \& Pedersen, M.B., 2003. Vegetation diversity of conventional and organic hedgerows in Denmark. Agric. Ecosyst. Environ. 99, 135-147.

Bäckman, J.P.C. \& Tiainen, J., 2002. Habitat quality of field margins in a Finnish farmland area for bumblebees (Hymenoptera: Bombus and Psithyrus). Agric. Ecosyst. Environ. 89, 53-68.

Bellosi, B., Trivellone, V., Jermini, M., Moretti, M. \& Schoenenberger, N., 2013. Composizione floristica dei vigneti del Cantone Ticino (Svizzera). Bollettino della Società ticinese di scienze naturali 101, 55-60.

Bengtsson, J., Ahnström, J. \& Weibull, A.C., 2005. The effects of organic agriculture on biodiversity and abundance: A meta-analysis. J. Appl. Ecol. $42,261-269$

Benton, T.G., Bryant, D.M., Cole, L. \& Crick, H.Q.P., 2002. Linking agricultural practice to insect and bird populations: a historical study over three decades. J. Appl. Ecol. 39, 673-687.

Benton, T.G., Vickery, J.A. \& Wilson, J.D., 2003. Farmland biodiversity: is habitat heterogeneity the key? Trends Ecol. Evol. 18, 182-188.

Bruggisser, O.T., Schmidt-Entling, M.H. \& Bacher, S., 2010. Effects of vineyard management on biodiversity at three trophic levels. Biol. Conserv. $143,1521-1528$.

Burel, F., 1996. Hedgerows and their role in agricultural landscapes. Crit. Rev. Plant Sci. 15, 169-190.

Conti, F., Abbate, G. \& Alessandrini, A., 2005. Annotated checklist of the Italian vascular flora. Palombi, Ancona.

Damgaard, C., Strandberg, B., Strandberg M., Aude, E., Borgen Sørensen, P., Nielsen K.E. \& Bruus, M., 2014. Selection on plant traits in hedgerow ground vegetation: The effect of time since conversion from conventional to organic farming. Basic Appl. Ecol. 15, 250-259.

Debras, J.F., Senoussi, R., Rieux, R., Buisson, E. \& Dutoit, T., 2008. Spatial distribution of an arthropod community in a pear orchard (Southern France) - Identification of a hedge effect. Agric. Ecosyst. Environ. 127, 166-176.

Dujmović Purgar, D. \& Hulina, N., 2004. Vineyard weed flora in the Jastrebarsko area (NW Croatia). Acta Bot. Croat. 63, 113-123.

Flohre, A., Fischer, C., Aavik, T., Bengtsson, J., Berendse, F., Bommarco, R., Ceryngier P., Clement, L.W., Dennis, C., Eggers, S., Emmerson, M., Geiger, F., Guerrero, I., Hawro, V., Inchausti, P., Liira, J., Morales, M.B., Oñate, J.J., Pärt, T., Weisser, W.W., Winqvist, C., Thies, C. \& Tscharntke, T., 2011. Agricultural intensification and bio-diversity partitioning in European landscapes comparing plants, carabids, and birds. Ecol. Appl. 21, 17721781.

Gago, P., Cabaleiro, C. \& García, J., 2007. Preliminary study of the effect of soil management systems on the adventitious flora of a vineyard in northwestern Spain. Crop Prot. 26, 584-591.

Gay, G., Bovio, M., Morando, A. \& Lembo, S., 1998. Evoluzione nella flora infestante di un vigneto trattato per un decennio con erbicidi non residuali. Atti Giornate Fitopatologiche.

Greaves, M.P. \& Marshall, E.J.P., 1987. Field margins: Definitions and statistics. In: Way, J.M. \& Greig-Smith, P.J. (eds). Field margins. Monograph 35, British Crop Protection Council, Thornton Heath, Surrey, UK. pp. $3-10$.

Hahn, M., Lenhardt, P.P \& Brühl, C.A., 2014. Characterization of field margins in intensified agro-ecosystems - Why narrow margins should matter in terrestrial pesticide risk assessment and management. Integr. Enviro. Assess. Manage. 10, 456-462.
Hole, D.G., Perkins, A.J., Wilson, J.D., Alexander, I.H., Grice, P.V. \& Evans, A.D., 2005. Does organic farming benefit biodiversity? Biol. Conserv. 122, 113-130.

Kleijn, D. \& Snoeijing, G.I.J., 1997. Field boundary vegetation and the effects of agro-chemical drift: Botanical change caused by low levels of herbicide and fertilizer. J. Appl. Ecol. 34, 1413-1425.

Krauss, J., Bommarco, R., Guardiola, M., Heikkinen, R.K., Helm, A., Kuussaari, M., Lindborg, R., Öckinger, E., Pärtel, M., Pino, J., Pöyry, J., Raatikainen, K.M., Sang, A., Stefanescu, C., Teder, T., Zobel, M. \& SteffanDewenter, I., 2010. Habitat fragmentation causes immediate and timedelayed biodiversity loss at different trophic levels. Ecol. Lett. 13, 597-605.

Longley, M., Çilgi, T., Jepson, P.C. \& Sotherton, N.W., 1997. Measurements of pesticide spray drift deposition into field boundaries and hedgerows: 1 . Summer applications. Environ. Toxicol. Chem. 16, 165-172.

Malcevschi, S., Bisogni, L.G. \& Gariboldi, A., 1996. Reti ecologiche ed interventi di miglioramento ambientale. Il Verde Editoriale, Milano.

Marshall, E.J.P. \& Moonen, A.C., 1998. A review of field margin conservation strips in Europe. A report for the UK Ministry of Agriculture, Fisheries and Food, IACR-Long Ashton Research Station.

Marshall, E.J.P. \& Moonen, A.C., 2002. Field margins in northern Europe Their functions and interactions with agriculture. Agric. Ecosyst. Environ. $89,5-21$.

Molina, G.A.R., Poggio, S.L. \& Ghersa, C.M., 2014. Epigeal arthropod communities in intensively farmed landscapes: Effects of land use mosaics, neighbourhood heterogeneity, and field position. Agric. Ecosyst. Environ. 192, 135-143.

Monteiro, A. \& Moreira, I., 2004. Reduced rates of residual and postemergence herbicides for weed control in vineyards. Weed Res. 44, 117128.

Nascimbene, J., Marini, L. \& Paoletti, M.G., 2012. Organic farming benefits local plant diversity in vineyard farms located in intensive agricultural landscapes. Environ. Manage. 49, 1054-1060.

Nascimbene, J., Marini, L., Ivan, D. \& Zottini M., 2013. Management intensity and topography determined plant diversity in vineyards. PLoS ONE 8(10), e76167.

Passarelli, D. \& Pirola, A., 1990. La flora spontanea dell'area della vite in Valtellina. Il naturalista valtellinese. Atti Museo civico di storia naturale di Morbegno 1, 79-114.

Pignatti, S., 1982. Flora d'Italia (vol. 1-3). Edagricole, Bologna.

Poggio, S.L., Chaneton, E.J. \& Ghersa, C.M., 2013. The arable plant diversity of intensively managed farmland: Effects of field position and crop type at local and landscape scales. Agric. Ecosyst. Environ. 166, 55-64.

Postma-Blaauw, M.B., De Goede, R.G.M., Bloem, J., Faber, J.H. \& Brussaard, L., 2012. Agricultural intensification and de-intensification differentially affect taxonomic diversity of predatory mites, earthworms, enchytraeids, nematodes and bacteria. Appl Soil Ecol. 57, 39- 49.

Regione Piemonte, 2009. Available at: http://www.regione.piemonte.it/ agri/politiche_agricole/viticoltura/dwd/statistica/5_0809.pdf

Schmitz, J., Schäfer, K. \& Brühl, C.A., 2013. Agrochemicals in field margins - Assessing the impacts of herbicides, insecticides, and fertilizer on the common buttercup (Ranunculus acris). Environ. Toxicol. Chem. 32, 1124-1131.

Schmitz, J., Hahn, M. \& Brühl, C.A., 2014a. Agrochemicals in field margins - An experimental field study to assess the impacts of pesticides and fertilizers on a natural plant community. Agric. Ecosyst. Environ. 193, 60-69. 
Schmitz, J., Schäfer, K. \& Brühl, C.A., 2014b. Agrochemicals in field margins - Field evaluation of plant reproduction effects. Agric. Ecosyst. Environ. 189, 82-91.

Simon, S., Bouvier, J.C., Debras J.F. \& Sauphanor, B., 2010. Biodiversity and pest management in orchard systems. A review. Agron. Sustainable Dev. 30, 139-152.

Sistema Piemonte, 2014. Available at: http:/www.sistemapiemonte.it/ fedwanau/viewer?CMDID $=$ columnNav_cse_PFC\&APNAME=sas actionProvider_olapViewer

Socher, S.A., Prati, D., Boch, S., Müller, J., Baumbach, H., Gockel, S., Hemp, A., Schöning, I., Wells, K., Buscot, F., Kalko, E.K.V., Linsenmair, K.E., Schulze, E.-D., Weisser, W.W. \& Fischer, M., 2013. Interacting effects of fertilization, mowing and grazing on plant species diversity of 1500 grasslands in Germany differ between regions. Basic Appl. Ecol. 14, 126136.

Thomson, L.J. \& Hoffmann, A.A., 2009. Vegetation increases the abundance of natural enemies in vineyards. Biol. Control 49, 259-269.

Trivellone, V., Schoenenberger, N., Bellosi, B., Jermini, M., De Bello, F., Mitchell, E.A.D. \& Moretti, M., 2014. Indicators for taxonomic and functional aspects of biodiversity in the vineyard agroecosystem of Southern Switzerland. Biol. Conserv. 170, 103-109.
Tscharntke, T., Klein, A.M., Kruess, A., Steffan-Dewenter, I. \& Thies, C., 2005. Landscape perspectives on agricultural intensification and biodiversity - ecosystem service management. Ecol. Lett. 8, 857-874.

Tscharntke, T., Tylianakis, J.M., Rand, T.A., Didham, R.K., Fahrig, L., Batáry, P., Bengtsson, J., Clough, Y., Crist, T.O., Dormann, C.F., Ewers, R.M., Fründ, J., Holt, R.D., Holzschuh, A., Klein, A.M., Kleijn, D., Kremen, C., Landis, D.A., Laurance, W., Lindenmayer, D., Scherber, C., Sodhi, N., Steffan-Dewenter, I., Thies, C., Van der Putten, W.H. \& Westphal, C. 2012. Landscape moderation of biodiversity patterns and processes - eight hypotheses. Biol. Rev. 87, 661-685.

Winqvist, C., Bengtsson, J., Aavik, T., Berendse, F., Clement, L.W., Eggers, S., Fischer, C., Flohre, A., Geiger, F., Liira, J., Pärt, T., Thies, C., Tscharntke, T., Weisser, W.W. \& Bommarco, R., 2011. Mixed effects of organic farming and landscape complexity on farmland biodiversity and biological control potential across Europe. J. Appl. Ecol. 48, 570-579.

Zhang, W., Ricketts, T.H., Kremen, C., Carney, K. \& Swinton, S.M., 2007. Ecosystem services and dis-services to agriculture. Ecol. Econ. 64, 253-260. 